\title{
Origin, Domestication, Current Status, Trend, Conservation and Management of Sheep Genetic Resource in Africa with Specific Reference to Ethiopia
}

\author{
Ahmedin Abdurehman \\ Department of Animal Science Oda Bultu University, P.O. Box 226, Chiro, Ethiopia
}

\begin{abstract}
Sheep were domesticated as dual purpose animals to produce wool and meat, early people would have valued sheep milk as well. The aim of this review was to describe the current status, trend, conservation and management of sheep genetic resource in Ethiopia. Sheep (Ovis aries) are believed to have been among the first animals to be domesticated (since $11000 \mathrm{BC}$ ), preceded by the dog and goat. Ethiopia is believed to be one of the major gateways for domestic sheep migration from Asia to Africa and has a diverse indigenous sheep population. Sheep are important sources of cash income and living banks to their owners. Sheep also play an important role in providing export commodities such as live animals and skins/leather to earn foreign currency. However, Sheep resources of Ethiopia are not well studied and there is practically no rational genetic conservation based improvement plan in the country.
\end{abstract}

Keywords: conservation, genetic, ovis, sheep.

DOI: $10.7176 / \mathrm{ALST} / 71-02$

\section{Introduction}

\subsection{Origin, Domestication and Distribution of Sheep}

The history of the domesticated sheep goes back to between 11000 and $9000 \mathrm{BC}$, and the domestication of the wild mouflon in ancient Mesopotamia.The exact line of descent between domestic sheep and their wild ancestors is unclear (Hiendleder S, et al., 2002). The most common hypothesis states that Ovis aries is descended from the Asiatic (O. orientalis) species of mouflon. A few breeds of sheep, such as the Castlemilk Moorit from Scotland, were formed through crossbreeding with wild European mouflon.

Sheep (Ovis aries) are believed to have been among the first animals to be domesticated, preceded by the dog and goat. The domestication of both sheep and goats probably dates back to the pre-settled agricultural period. It is also believed that most domestication took place in western Asia where the majority of the present day small ruminant breeds likely originated. Existence of some ancestral stock of wild sheep extends from Western Europe to China. These are: 1, the mouflon of Europe, the Middle East (Asia Minor), and western Iran, 2, the urial of western Asia and Afghanistan, 3, the argali of central Asia, and 4, the bighorn of northern Asia and North America.

It is assumed that the majority of today's domestic sheep breeds descended from the urial which is currently found in central Asian countries and in northern Iran extending up to Tibet and northern China. The hair sheep of Africa and Asia are thought to have descended mainly from the urial. The argali is believed to have played a significant role in the development of domesticated sheep of India and the Far East.

Sheep entered the African continent not long after their domestication in western Asia. A minority of historians once posited a contentious African theory of origin for Ovis aries (Blench, et al., 1999). This theory is based primarily on rock art interpretations, and osteological evidence from Barbary sheep (Blench, et al., 1999). The history of introduction of sheep into Africa recognizes (Epstein 1971) three waves of migration from Asia of precursor populations (thin-tailed, fat-tailed and fat-rumped sheep, respectively). The earliest sheep in Africa were thin-tailed and hairy, and were introduced to East Africa via North Africa (Marshal 2000). The second wave of sheep introduction constitutes fat-tailed sheep entering North Africa via the Isthmus of Suez and East Africa via straits of Bab-el-Mandeb (Ryder 1984). Fat-rumped sheep entered East Africa much later (Epstein 1954; Epstein 1971; Ryder 1984). Accordingly, African sheep have been described and classified based on their tail type (Epstein 1971; Ryder 1984).

The first sheep entered North Africa via Sinai, and were present in ancient Egyptian society between eight and seven thousand years ago. Sheep have always been part of subsistence farming in Africa, but today the only country that keeps significant numbers of commercial sheep is South Africa, with 28.8 million head ( $A$ PROFILE OF THE SOUTH AFRICAN MUTTON MARKET VALUE CHAIN, 2013)

A few research projects have addressed the origins of Ethiopian sheep. African sheep are thought to be of Near Eastern origin (Epstein 1954; Epstein 1971; Ryder 1984; Marshal 2000) and Ethiopia is believed to be one of the major gateways for domestic sheep migration from Asia to Africa (Devendra and McLeroy 1982).

Ethiopia has a diverse indigenous sheep population numbering 23.6 million. Sheep contribute significantly to farm livelihoods, particularly where crop production is unreliable and where livestock is the mainstay of 
livelihoods (i.e., pastoral areas) (Desta Hamito, 2009).

In Ethiopia, there are several varieties of sheep landrace. Attempts have been made to classify the sheep based on factors such as tail shape and wool type, and H. Epstein made an attempt at classifying them this way by dividing the breeds into 14 types based on those two factors. However, in 2002, further genetic analysis revealed that there are only four distinct varieties of Ethiopian sheep: short-fat-tailed, long-fat-tailed, fat-rumped, and thin-tailed (Solomon G. et al, 2011).

In Ethiopia, there exists a great variation in climate and topography, harboring diversified livestock species which also have variability among themselves. The sheep found in Ethiopia could fall into different breeds and types whose habitat ranges from tropical to temperate environments. The present fat-tailed sheep of Ethiopia that are believed to have replaced the original African long-thin-tailed sheep came from Asia through the Strait of Bab El Mandeb (ESGPIP).

Although sheep were domesticated as dual purpose animals to produce wool and meat, early people would have valued sheep milk as well. The aim of this review was to review on the current status, trend, conservation and management of sheep genetic resource in Ethiopia.

\section{Review on current status, trend, conservation and management of sheep genetic resource in Ethiopia}

\subsection{Current status of sheep in Ethiopia}

Ethiopia is endowed with diverse agro-ecological zones and corresponding large and diverse sheep resources numbering about 28.3 million heads (CSA, 2015). Sheep are important sources of cash income and living banks to their owners (Markos T., 2006 and Tsegaye, T. et al, 2013). Sheep also play an important role in providing export commodities such as live animals and skins/leather to earn foreign currency (Getachew T., et al, 2010). Sheep account for $19 \%$ and $95 \%$ of the total livestock and small ruminant live animal export, respectively (Hailemariam, F. et al, 2013).

Ethiopia's lowland sheep and goat breeds are in high demand in neighboring and Middle East countries. Lowland breeds are more preferred than highland breeds by exporters (Aseged, T. et al, 2015). The performance of the sheep industry has been poor compared with other African countries due to inadequate feed and nutrition, widespread disease and health problem, poor management and marketing system (Gizaw, S. et al., 2010 and IGAD, 2011).

The current sheep production may not be meeting the increasing domestic demand due to increased human population and urbanization (Legese, G. et al., 2014) There is also increasing demand for sheep and sheep products in the neighboring countries like Sudan and North African countries, which is an opportunity for producers. Northwestern lowland of Amhara region is among the high potential areas for livestock production and for the supply of live animals to the Sudan market (Mulugeta, E., et al., 2007) and used either for local consumption or for re-exporting to Egypt, Libya and Yemen. The major sheep breeds kept in this area are Gumz, Rutana and their crossbred. The local Gumz sheep are prolific, adaptable to the hot environmental condition of the area and known for their tasty meat (Solomon, A., 2011). High human population growth and improvement of living standard increase the demand for animal protein, which consequently leads to bulk supply of the best animals and crossing with exotic breeds to meet the demand for large number and best animals in the market. This is seriously threatening the existence of indigenous populations. Hence, the current drive for rapid livestock development through crossbreeding and the threat status of indigenous sheep (Gizaw, S. et al, 2013) requires research to design and implement suitable breeding strategies so as to improve productivity and conserve indigenous breeds.

\section{Sheep breeds of Ethiopia}

There are about 14 traditionally recognized sheep populations in Ethiopia. These populations are called sheep types in some literatures. They are also designated as breeds according to some definitions of 'breed'. The sheep types are named after their geographic location and/or the ethnic communities keeping them.

The sheep types in Ethiopia are classified into four major groups based on their physical characteristics: short fat-tailed, long fat-tailed, thin-tailed and fat-rumped sheep. Based on DNA differences, Ethiopian sheep types have been classified into nine genetically distinct breeds (Solomon Gizaw, 2008).

Indigenous sheep breeds: Major sheep breeds found in Ethiopia are Begayit, Farta, Horro, Abergelle, Menz, Begi-Degu, Arsi, Ille, Tukur, Bonga, Afar, Dangila and Black Head Somali (formerly known as Black Head Ogaden) sheep breeds. Farta sheep breed (found in South Gondar Zone of Amhara Regional State), and Abergelle, Begi-Degu and Ille sheep breeds (found in Tigray Regional State) have been reported recently by the agricultural bureau of the respective regions. 
Table 1. Major groups, breeds and sheep types ${ }^{1}$ of sheep in Ethiopia

\begin{tabular}{lllll}
\hline Major group & Breed $^{2}$ & Sheep types $^{3}$ & Tail type/shape & Fiber type \\
\hline Short-fat-tailed & Simien & Simien & Fatty and short & Wool/fleece \\
& Short fat-tailed & Sekota, Farta, Tikur, Wollo, Menz & Fatty and short & Wool/fleece \\
& Washera & Washera & Fatty and short & Short hair \\
Long-fat-tailed & Horro & Horro & Fatty and long & Short hair \\
& Arsi-Bale & Arsi-Bale, Adilo & Fatty and long & Short hair \\
& Bonga & Bonga & Fatty and long & Short hair \\
Fat-rumped sheep & Afar & Afar & Fat rump with fat tail & Short hair \\
& Black head Somali & Black head Somali & Fat rump/tiny tail & Short hair \\
Thin-tailed sheep & Gumz & Gumz & Thin and long & Short hair \\
\hline
\end{tabular}

${ }^{1}$ It should be noted that some breeds in neighboring countries could be found in border areas in small numbers.

These breeds are not included here. Example, Nuer sheep (found in the Gambella region and maintained by the Nuer community), Barka or Begayit in the Tigray region. ${ }^{2}$ Based upon DNA analysis. ${ }^{3}$ Based upon tradition.

Exotic sheep breeds: Exotic sheep breeds introduced for their wool and mutton production are Awassi, Hampshire, Blue-de-main, Merino, Romney, Corriedale and Dorper. Crossbreeding of the Menz breed with the five exotic breeds, namely: Awassi, Hampshire, Bleu-de-Main, Romney and Dorper are being used for development and research activities.

In Ethiopia, various sheep production system categories are practiced, namely highland sheep-barley system, mixed crop-livestock system, pastoral and agro-pastoral production system, ranching, and Urban and peri-urban (UPU) sheep production system (Solomon et al., 2008)

\subsection{Trend of sheep genetic resource in Ethiopia}

Sheep have social and economic importance to the producers who keep indigenous breeds for meat, hair production and income generation. The sheep have coarse fleece and a coat of short or long hair. To improve their productivity, the former MoA has drafted two development strategies (1) to improve and select a program for indigenous sheep with higher potential, and (2) to crossbreed small- to medium-sized local breeds with the exotics where there is no other choice for improvement. In 1981, ARDU (Arsi Rural Development Unit) started a breeding program on indigenous breeds which involved

(1) Crossbreeding exotic with indigenous sheep to study the performance of different levels of crossing and (2) producing crossbred rams to be distributed to farmers.

The indigenous breeds involved in this program were Arsi, Bonga, Horro, Black Head Somali and Afar. Rams of exotic breeds involved in the program were Bleu-de-Main, Corriedale, Romney and Hampshire (Institute of Biodiversity Conservation, 2004).

The then MoA also established three sheep breeding and multiplication ranches in different parts of the country. The main objectives of these ranches were to improve meat and wool production of the indigenous sheep through selection and crossbreeding. The indigenous breeds that were involved under these programs were Black Head Somali, Menz and Horro.

The former Institute of Agricultural Research (IAR), higher teaching institutions like Haramaya University (HU), the Ambo and Jimma Junior Agricultural Colleges and ARDU carried out research activities on sheep. Most of the research activities focused on performance testing of crossbred sheep at different blood levels and to some extent breed evaluation of the indigenous Arsi, Horro, Black Head Somali and Afar sheep breeds (IBC, 2004).

Demand for animal products in developing countries is projected to rise significantly and faster than in developed countries as a result of population growth, urbanization and rising incomes. Greater consumption diversification or changes in food patterns are likely to occur in the developed countries, as a larger proportion of consumers require a more varied menu of a higher quality (Delgado et. al., 1999).

Output of meat and milk in Ethiopia is low and growth in productivity has been lagging behind population growth rates. As a consequence, the trend in per caput output of livestock products has been negative. Between 1995 and 2000, total milk and meat production increased by $2.6 \%$ and $1.4 \%$ per year, respectively.

According to Genet Mengistu (2004) with an estimated annual growth rate of $2.7 \%$, the population of Ethiopia is projected to increase from 63.5 million in 2000 to 84.0 million in 2010 and 106.0 million in 2020 . This illustrates the wide gap in per capita consumption of animal products between Ethiopia, Sub-Saharan Africa (SSA) and developed countries and signifies the link between population growth and declining per capita animal food availability (FAO, 2001).

Market-oriented and demand driven opportunities for growth exist where population concentration is increasing. A study on urban demand for live sheep showed that sheep prices and household income, as well as 
socio-demographic factors, including household size and composition, significantly affect the likelihood of buying and expenditures on live sheep. Projections of live sheep demand and supply in Addis Ababa in 2010 and 2020 showed that sheep producers in Addis Ababa alone will be able to meet up to only $27 \%$ of the demand (Ehui et. al., 2000). Thus, the impact of population growth plus urbanization will provide impetus for livestock development.

The future breeding policy on development and conservation of AnGR should include, among other things, strategies and guidelines for farmers, researchers, extension workers and animal breeds that are suitable for the various agro-ecological zones. It should also include alternative breeding programs, regulations of import and export of genetic materials, characterization, conservation and sustainable use of indigenous genetic resources and use of modern breeding technologies (Institute of Biodiversity Conservation, 2004).

\subsection{Conservation of sheep genetic resource in Ethiopia}

All human activities, including strategies, plans, policies and actions undertaken to ensure that the diversity of farm animal genetic resources is being maintained to contribute to food and agriculture production and productivity, now and in the future.

The primary objective of livestock conservation for developing countries is conservation for sustainable use (Ruane J. et al., 2000 and Simon D.L., 1999). Conservation is not only about endangered breeds but also about those that are not being utilized efficiently (Barker J.S.F., 2001). Conservation aims of farm animal genetic resources range from avoiding extinction, maintaining genetic diversity and/or the cultural, ecological or socioeconomic values of breeds, to providing the right conditions for their evolution within an evolving production system (Barker J.S.F., 2001)

Sheep resources of Ethiopia are not well studied and there is practically no rational conservation-based improvement plan in the country. With 14 traditionally recognized breeds (Gizaw S. et al., 2007) Ethiopia possesses highly diversified and adapted indigenous sheep populations parallel to its highly diverse agro-ecology, ethnic communities and production systems (Galal. et al., 1983). However, changes in production systems, in response to socio-economic factors, have led to the use of exotic germplasm, endangering the survival of the adapted indigenous breeds. Besides, population sizes and flock structures of some populations are currently not commensurate with optimal genetic resource management levels (S. Gizaw et al., 2008).

Research and development on conservation of sheep genetic resources in Ethiopia are limited. Major accomplishments include the extensive characterization and documentation of breed information by IBC (FAO 2007) and DAGRIS (Domestic Animal Genetic Resource Information System).

Recent research approaches to conserve sheep genetic resources have developed breeding strategies for sustainable and rational utilization of indigenous breeds. Developing rational crossbreeding programs is necessary to strike a balance between increasing livestock productivity and conserving indigenous resources.

Sheep genetic resource conservation is sustainable utilization sheep resource or it is using our sheep resources to fulfill our current requirements while maintaining them for future use. The first step in conservation is to know which breed to conserve. This can be done through characterization.

\subsubsection{Conservation methods}

1. Ex situ conservation: is done through cryo-preservation of animal germplasm by storing sperm, oocytes and embryos and also through preservation of live animals of endangered breeds out of the area where they are originally kept. For cryo-preservation technique to be effective, progeny of at least 25 sires should be stored. The facilities in Ethiopia for this technique are not well developed. The germplasm can be collected in Ethiopia and may be stored in countries where facilities are available.

2. In situ conservation: is the preservation, multiplication and utilization of indigenous breeds in their native habitats and maintenance of pure breeds or strains. The minimum number of animals recommended for sheep is 60 and the maximum is 1500 ewes. Special conservation flocks can be established as part of the cultural heritage for endangered breeds or breeds in critical status. Nucleus breeding flocks can be established in cooperative breeding programs to supply breeding stock to farmers

\section{Guidelines for sustainable utilization}

1. Conserve the adapted indigenous breeds as they have special adaptive and productive merits.

$>$ Conserve breeds through utilization. The rationale is that we need to use the breeds to improve our livelihoods.

$>$ Improve competitiveness of local breeds! Increase their value to the communities. In Ethiopia, there is a tendency to replace the local breeds with improved exotic breeds. This is because the locals are perceived to be inferior in productivity. Competitiveness of local breeds could be increased by improving their productivity.

2. Productivity can be improved in two ways:

$>$ Improving the production environment (feed, disease control/prevention) and 
$>$ Improving genetic merit.

$>$ Genetic improvements should maintain adaptive merits of breeds

> Genetic improvement options should consider environment of the breeds. For example, crossbreeding should not be an option in low potential areas.

$>$ Improve the breed for what it lacks. The productive merits and demerits need to be considered.

Genetic improvement options are selective breeding and crossbreeding.

I. Selective breeding is a sustainable option to improve genetic merits.

II. Crossbreeding can also be utilized sustainably

There are exotic breeds with good productive merits in the country: $3 / 4$ Awassi good for meat and coarse wool for carpet weaving $3 / 4$ Corriedale good for fine wool production used for weaving gabi. 3/4 Dorper for meat production $3 / 4$ Rutana for meat production; adapted to arid pastoral system. The Rutana is introduced from The Sudan and is found in the western lowlands (Metema area) of Ethiopia (Solomon Abegaz and Kassahun Awgichew, 2002).

- Indiscriminate crossbreeding should be avoided! Breeding must be controlled.

- Terminal crossbreeding is an option for a controlled crossbreeding.

- Terminal crossbreeding can increase farmers' income from the sale of crossbred lambs while conserving local flocks.

- Terminal crossbreeding involves selling all crossbred lambs except the ram maintained for subsequent breeding.

\subsection{Management of sheep genetic resource in Ethiopia}

A breed is a unit for the management of a farm animal genetic resource. It is a group of similar animals within a species. When characterizing a livestock population and production system in order to inform sustainable utilization of the livestock resources, emphasis should be given to farmers' and pastoralists' indigenous knowledge that relate to the management of the genetic resources in question (Solomon G. et al., 2011). Classification of production systems was based on the level of livestock production and its contribution to the community as well as the type of crop production enterprises. The livestock production systems have also been described in relation to the sheep breeds (Gizaw et al. 2008a). The systems have been well described in terms of the production environment such as feed resources and important diseases, major constraints to sheep production, flock characteristics, farmers' sheep breeding and management practices, farmers breeding objectives, agricultural service delivery and sheep marketing. A summary of production systems in relation to sheep breeds in Ethiopia is presented in the following Table.

Table 8. Major sheep production systems in Ethiopia

\begin{tabular}{|c|c|c|c|c|}
\hline \multirow[b]{2}{*}{$\begin{array}{l}\text { Production } \\
\text { systems }\end{array}$} & \multirow[b]{2}{*}{ Environment } & \multirow[b]{2}{*}{ Geographic regions } & \multicolumn{2}{|c|}{ Characteristic features of production systems } \\
\hline & & & Main products & $\begin{array}{l}\text { Scale of production and } \\
\text { management }{ }^{\dagger}\end{array}$ \\
\hline $\begin{array}{l}\text { Subalpine sheep- } \\
\text { cereal system }\end{array}$ & Subalpine $(>3000 \mathrm{~m})$ & $\begin{array}{l}\text { Menz area, Wag Himra, parts of } \\
\text { North Gondar (Debark, Dabat, } \\
\text { Janamora,Wegera), South } \\
\text { Gondar, North and south } \\
\text { Wollo zones of Amhara state, } \\
\text { and Tigray State }\end{array}$ & $\begin{array}{l}\text { Meat, fiber, manure, } \\
\text { skin; unreliable, long- } \\
\text { season barley }\end{array}$ & $\begin{array}{l}\text { Medium scale sheep } \\
\text { production; Semi- } \\
\text { intensive/extensive, } \\
\text { low-input }\end{array}$ \\
\hline $\begin{array}{l}\text { Highland cereal- } \\
\text { livestock system }\end{array}$ & $\begin{array}{l}\text { Highlands (2000-3000 } \\
\text { m) }\end{array}$ & $\begin{array}{l}\text { Most of Oromia; West and East } \\
\text { Gojam and Agew Awi zones of } \\
\text { Amhara state; Central Tigray }\end{array}$ & $\begin{array}{l}\text { Mainly cereal } \\
\text { cropping; meat, } \\
\text { manure, skin }\end{array}$ & $\begin{array}{l}\text { Small-scale sheep } \\
\text { production; semi- } \\
\text { intensive, low-input }\end{array}$ \\
\hline $\begin{array}{l}\text { Highland } \\
\text { perennial crop } \\
\text { system }\end{array}$ & $\begin{array}{l}\text { Highlands(1500-2000 } \\
\mathrm{m})\end{array}$ & $\begin{array}{l}\text { Coffee, Inset and fruit growing } \\
\text { areas of Southern and Oromia }\end{array}$ & $\begin{array}{l}\text { Mainly perennial cash } \\
\text { crops (coffee, inset, } \\
\text { khat); meat, skin }\end{array}$ & $\begin{array}{l}\text { Minor sheep production; } \\
\text { semi-intensive, low- } \\
\text { input; some practice } \\
\text { tethering }\end{array}$ \\
\hline $\begin{array}{l}\text { Lowland crop- } \\
\text { livestock system } \\
\text { (agropastoral) }\end{array}$ & $\begin{array}{l}\text { Submoist/moist } \\
\text { lowland }(\leq 1000 \mathrm{~m})\end{array}$ & $\begin{array}{l}\text { Benishangul-Gumz, lowlands of } \\
\text { Amhara,Tigray, Oromia }\end{array}$ & $\begin{array}{l}\text { Cereals, sesame, } \\
\text { cotton; meat, skin }\end{array}$ & $\begin{array}{l}\text { High level of livestock } \\
\text { keeping; extensive/semi- } \\
\text { intensive, low-input }\end{array}$ \\
\hline Pastoral system & $\begin{array}{l}\text { Semi-arid/arid }(\leq 1000 \\
\mathrm{m})\end{array}$ & $\begin{array}{l}\text { Pastoral regions in Somali,Afar, } \\
\text { Oromia and southern states }\end{array}$ & $\begin{array}{l}\text { Meat, milk, skin; } \\
\text { minimal or no } \\
\text { cropping }\end{array}$ & $\begin{array}{l}\text { Rangeland-based large- } \\
\text { scale sheep production; } \\
\text { extensive, low-input }\end{array}$ \\
\hline
\end{tabular}

+ Based on feeding. veterinary care, housing practices

Adapted from Gizaw et al. (2008). 


\section{Conclusion}

Sheep (Ovis aries) are believed to have been originated and domesticated in Asia and gradually introduce to Africa through migration. Ethiopia is endowed with diverse agro-ecological zones and corresponding large and diverse sheep resources which is the main sources of cash income also play an important role in providing export commodities to earn foreign currency. However, Sheep resources of Ethiopia are not well studied and there is practically no rational genetic conservation based improvement plan in the country.

\section{Reference}

A PROFILE OF THE SOUTH AFRICAN MUTTON MARKET VALUE CHAIN (PDF). Department of Agriculture, Forestry and Fisheries. Retrieved September 17, 2013.

Asegede, M., Bisrat, A., Hagos, Y. and Gugsa, G. 2015 Livestock Market Value Chain Assessment in Selected Sites of Tigray, North Ethiopia: Challenges and Opportunities for Enhancing Animal Product Export. Global Veterinaria , 14, 48-55.

Barker J.S.F., (2001). Conservation and management of genetic diversity: a domestic animal perspective, Can. J. Forest Res. 31, 588-595.

Blench, Roger; Kevin C MacDonald 1999. The Origins and Development of African Livestock. Routledge. ISBN 1-84142-018-2.

Breeds of Livestock. Oklahoma State University Dept. of Animal Science. Retrieved 2008-01-27.

CSA (Central Statistics Agency) (2015) Agricultural Sample Survey 2014/15. Volume II Report on Livestock and Livestock Characteristics (Private Peasant Holdings), Central Statistical Agency (CSA), Addis Ababa, Ethiopia, $188 \mathrm{p}$.

Delgado, C., M. Rosegrant, H. Steinfeld, S. Ehui, and C. Courbois 1999. Livestock to 2020. The Next Food Revolution. Food, Agriculture and the Environment Discussion Paper 28.

Desta Hamito 2009. Sheep breeds of Ethiopia: A guide for identification and utilization technical bulletin No.28 by the Ethiopia Sheep and Goat Productivity Improvement Program (ESGPIP).

Devendra, C. and McLeroy, G.B. 1982. Goat and sheep production in the tropics. London, UK: Longman.

Ehui S.K., Benin S. and Nega Gebreselassie 2000. Factors affecting urban demand for live sheep: The case of Addis Ababa, Ethiopia. Socio-economics and Policy Research Working Paper 31. ILRI (International Livestock Research Institute), Nairobi, Kenya. 32 pp.

Epstein, H. 1954. The fat-tailed sheep of east Africa. The East African Agricultural Journal 20:109-17.

Epstein, H. 1971. The origin of domestic animals of Africa. Vol. 2. New York, USA: Africana Publication Corporation.

Food and Agriculture Organization 2001. FAOSTAT. FAO statistical databases on agriculture, fisheries, forestry and nutrition, Rome, Italy.

Galal E.S.E., 1983. Sheep germplasm in Ethiopia, Anim. Genet. Res. Inf. 1, 4-12.

Genet Mengistu 2004. Population and development in Ethiopia. A Paper presented at Women's Forum ACP-EU Joint Parliamentary Assembly, Feb. 14, 2004, UN CON. Center, Addis Abeba, Ethiopia.

Getachew, T., Haile, A., Tibbo, M., Sharma, A.K., Sölkner, J. and Wurzinger, M. 2010 Her Management and Breeding Practices of Sheep Owners in a Mixed Crop-Livestock and a Pastoral System of Ethiopia. African Journal of Agricultural Research , 5, 685-691.

Gizaw S. 2008. Sheep resources of Ethiopia: Genetic diversity and breeding strategies. PhD thesis. Wageningen, the Netherlands: Wageningen University.

Gizaw S., van Arendonk J.A.M., Komen H., Windig J.J., Hanotte O. 2007. Population structure, genetic variation and morphological diversity in indigenous sheep of Ethiopia, Anim. Genet. 38, 621-628.

Gizaw, S., Abegaz, S., Rischkowsky, B., Haile, A., Mwai, A.O. and Dessie, T. 2013. Review of Sheep Research and Development Projects in Ethiopia. International Livestock Research Institute (ILRI), Nairobi, Kenya.

Gizaw, S., Haile, A. and Dessie, T. 2010. Breeding Objectives and Breeding Plans for Washera Sheep under Subsistence and Market Oriented Production Systems. Ethiopian Journal of Animal Production, 10, 1-16.

Hailemariam, F., Melesse, A. and Banerjee, S. 2013 Traditional Sheep Production and Breeding Practice in Gamogofa Zone, Southern Ethiopia. International Journal of Livestock Production Research, 1, 26-43.

Hiendleder S, Kaupe B, Wassmuth R, Janke A. 2002. "Molecular analysis of wild and domestic sheep questions current nomenclature and provides evidence for domestication from two different subspecies" (PDF). Proc. Biol. Sci. 269 (1494): 893-904.

Institute of Biodiversity Conservation 2004. The State of Ethiopia's Farm Animal Genetic Resources: Country Report. A Contribution to the First Report on the State of the World's Animal Genetic Resources. IBC. May 2004. Addis Ababa, Ethiopia.

Kassahun Awgichew and Solomon Abegaz. Ethiopia Sheep and Goat Productivity Improvement Program, chapter two Breeds of Sheep and Goats.

Legesse, G., Haile, A., Duncan, A.J., Dessie, T., Gizaw, S. and Rischkowsky, B. 2014. Sheep and Goat Value 
Chains in Ethiopia: A Synthesis of Opportunities and Constraints. ICARDA/ILRI Project Report, International Center for Agricultural Research in the Dry Areas/International Livestock Research Institute, Nairobi, Kenya.

Markos, T. 2006. Productivity and Health of Indigenous Sheep Breeds and Crossbreds in the Central Ethiopian Highlands. PhD Dissertation, Department of Animal Breeding and Genetics, Faculty of Veterinary Medicine and Animal Sciences, Swedish University of Agricultural Science (SLU), Uppsala, Sweden, 74 p.

Marshal, F. 2000. The origins and spread of domestic animals in East Africa. In: Blench, R.M. and MacDonald, K.C. (eds), The origins and development of African livestock: Archaeology, genetics, linguistics and ethnography. London, UK: University College London Press. pp. 191-218.

Mulugeta, E., Gebremedhin, B., Hoekstra, D. and Mohammed, J. 2007. Analysis of the Ethio-Sudan CrossBorder Cattle Trade: IPMS (Improving Productivity and Market Success) of Ethiopian Farmers Project Working Paper 2. ILRI (International Livestock Research Institute), Nairobi, Kenya.

Ruane J., 2000. A framework for prioritizing domestic animal breeds for conservation purposes at the national level: a Norwegian case study, Conserv. Biol. 14, 1385-1393.

Ryder, M.L. 1984. Sheep. In: Mason, I.L. (ed), Evolution of domestic animals. London, UK: Longman. pp. 6385.

Simon D.L., 1999. European approaches to conservation of farm animal genetic resources, Anim. Genet. Res. Inf. 25, 77-97.

Solomon Abegaz and Kassahun Awgichew. Ethiopia Sheep and Goat Productivity Improvement Program, chapter six Genetic Improvement of Sheep and Goats.

Solomon Gizaw; H. Komen; O. Hanotte; J.A.M. Van Arendonk; S. Kemp; Aynalem Haile; O. Mwai; Tadelle Dessie 2011. "2.2.5.1 Significant morphological characters". Characterization and Conservation of Indigenous Sheep Genetic Resources: a Practical Framework for Developing Countries. ILRI (aka ILCA and ILRAD). pp. 16-17.

Solomon Gizaw, Komen, H., Hanote, O., van Arendonk, J.A.M., Kemp, S., Aynalem Haile, Mwai, O. and Tadelle Dessie. 2011. Characterization and conservation of indigenous sheep genetic resources: A practical framework for developing countries. ILRI Research Report No. 27. Nairobi, Kenya, ILRI.

Solomon, A., Hegde, B.P. and Mengistie, T. 2011. Growth and Physical Body Characteristics of Gumuz Sheep under Traditional Management Systems in Amhara Regional State, Ethiopia. Livestock Research for Rural Development, 23, 1-5.

Solomon, M. and Simret, B. 2008. Bodyweight and carcass characteristics of somali goats fed hay supplemented with graded levels of peanut cake and wheat bran mixture. Trop Anim Health Prod., 42:553-560.

Takekazu Ogura 1963. Agricultural development in modern Japan. Fuji Pub. Co. pp. 569-570.

Tsegaye, T., Mengistu, U., Yoseph, M. and Merga, B. 2013. Pre-Weaning Growth Performance of Crossbred Lambs (Dorper $\times$ Indigenous Sheep Breeds) under Semi-Intensive Management in Eastern Ethiopia. Tropical Animal Health and Production, 46, 455-460 